\title{
Expression of cyclo-oxygenase types-1 and -2 in human fetal membranes throughout pregnancy
}

\section{Slater, W Dennes, R Sawdy, V Allport and P Bennett}

\author{
Parturition Research Group, Imperial College School of Medicine, Institute of Obstetrics and \\ Gynaecology, Queen Charlotte's and Chelsea Hospital, Goldhawk Road, London W6 0XG, UK
}

(Requests for offprints should be addressed to D Slater)

\begin{abstract}
Human labour is associated with increased prostaglandin synthesis within the fetal membranes. We have studied the expression of the two isoforms of the central prostaglandin synthetic enzyme, cyclooxygenase (COX-1 and COX-2), in human fetal membranes throughout pregnancy, at mRNA, protein and activity levels.

COX-1 mRNA expression was low in human amnion and chorion-decidua and did not change with gestational age. COX-2 mRNA expression in fetal membranes increased with gestational age, with significant up-regulation prior to the onset of labour and in association with labour. Protein concentrations of COX-1 did not change, whilst
\end{abstract}

concentrations of COX-2 increased from the first to the third trimester. COX activity increased with gestational age and in association with labour, although prostaglandin production in fetal membranes collected after labour was reduced, suggesting reduced substrate supply.

These data suggest that it is up-regulation of COX-2, rather than of COX-1, which mediates increased prostaglandin synthesis within the fetal membranes at term. Much of the increase in COX-2 expression precedes the onset of labour, suggesting that it is a cause, rather than a consequence, of labour.

Fournal of Molecular Endocrinology (1999) 22, 125-130

\section{INTRODUCTION}

There is considerable evidence to support a central role for prostaglandins in human parturition. Labour is associated with increased prostaglandin synthesis within the uterus (Keirse et al. 1977), particularly from the fetal membranes (Skinner \& Challis 1985). Prostaglandins mediate cervical ripening, and directly stimulate uterine contractions (Crankshaw \& Dyal 1994) and indirectly increase fundally dominant myometrial contractility by up-regulation of oxytocin receptors and synchronisation of contractions (Liggins 1989, Garfield et al. 1990).

Prostaglandins are formed from the precursor arachidonic acid, which itself is a substrate for at least three enzyme groups. The cyclo-oxygenase (COX) pathway produces prostaglandins. The lipoxygenase enzyme pathways produce a series of hydroxyeicosatetraenoic acids (HETEs). Arachidonic acid metabolism via epoxygenase pathways produces epoxyeicosatetraenoic acids. Prior to labour, endogenous arachidonic acid metabolism in amnion is principally via the lipoxygenase enzyme pathways. With labour, there is an increase in arachidonic acid metabolism and a change in the ratio of COX to lipoxygenase metabolism to favour synthesis of prostaglandin $\mathrm{E}_{2}$ (Saeed \& Mitchell 1982, Bennett et al. 1993). The roles of the lipoxygenase metabolites of arachidonic acid within the uterus are unknown, although 5-HETE may play a role in pre-labour (Braxton-Hicks) contractions (Bennett et al. 1987, Walsh 1989).

The switch from lipoxygenase to COX metabolism implies up-regulation of COX. Two COX genes have been described, the constitutively expressed COX-1 and the inducible COX-2 (Hla et al. 1986, Hla \& Neilson 1992). In situ hybridisation has localised expression of COX-1 and COX-2 mRNA in the fetal membranes (Slater et al. 1995). Expression of COX-2 is mainly within the amnionic epithelial layer and also in cells of the amnionic mesoderm, and in the reticular layer of both chorion and decidua. COX-2 is not expressed in the trophoblast layer of the chorion. COX-1 expression is more diffuse, and is seen in the amnionic epithelium, amnionic mesoderm and also in the chorionic mesoderm and decidua. In amnion 
at term, expression of the COX-2 mRNA is some 100 -fold higher than that of COX-1 mRNA. The expression of COX-2 doubles in association with labour (Slater et al. 1994, 1995, Hirst et al. 1995). In chorion-decidua at term, COX-2 mRNA is 8 -fold more abundant than COX-1 mRNA, and COX-2 expression increases 4-fold in association with labour (Slater et al. 1998). Enzyme kinetic studies suggest that the increase in COX activity with the onset of labour is due entirely to an increase in the synthesis of the COX enzyme (Smieja et al. 1993).

There is conflicting evidence as to whether the increased prostaglandin synthesis associated with labour is a cause or an effect of labour. MacDonald \& Casey (1993) found that the increase in prostaglandin concentrations in the amniotic fluid occurred earlier and was greater in the fore-bag (in front of the fetal head) compared with the hind-bag, and that hind-bag prostaglandin concentrations in early labour were not increased above pre-labour concentrations. They inferred from these data that prostaglandin formation was a consequence of labour. However, studies where sequential amniocentesis was performed, on patients before and during labour, showed that increased prostaglandin concentrations preceded the onset of labour (Romero et al. 1996).

In this study we have examined COX-1 and COX-2 mRNA, protein and activity levels in human fetal membranes at different stages of pregnancy. We have tested the hypothesis that up-regulation of COX-2 within the human fetal membranes occurs before the onset of labour and is therefore a cause, and not a consequence, of labour.

\section{MATERIALS AND METHODS}

\section{Tissue samples}

For mRNA studies, fetal membranes were collected with consent and ethics committee approval between 6 and 22 weeks at surgical termination of pregnancy, between 28 and 37 weeks at elective caesarean section prior to the onset of labour, in cases of maternal cardiac, renal or hypertensive disease, and after 38 weeks at elective caesarean section prior to labour in cases of breech presentation or previous caesarean section.

\section{Reverse transcription-polymerase chain reaction (RT-PCR)}

RT-PCR was performed as previously described (Slater et al. 1995). Primers used were: COX2 sense (5'-TTCAAATGAGATTTGGGAAAAT
TGCT), COX-2 antisense (5'-AGATCATCTCT GCCTGAGTATCTT), COX-1 sense (5'-TGCCC AGCTCCTGGCCCGCCGCTT), COX-1 antisense (5'-CCATGGCCCAAGGCCTTG), glyceraldehyde 3-phosphate dehydrogenase (GAP) DH sense (5'-CCACCCATGGCAAATTCCATGGCA), GAPDH antisense (5'-TCTAGACGGCAGGTCA GGTCCACC) (Hla et al. 1986, Hla \& Neilson 1992). The reaction cycles were denaturing at $94{ }^{\circ} \mathrm{C}$ for $30 \mathrm{~s}$, annealing at $58{ }^{\circ} \mathrm{C}$ for $30 \mathrm{~s}$ and extension at $72{ }^{\circ} \mathrm{C}$ for $30 \mathrm{~s}$.

To determine the exponential phase of amplification, where product formation is related to starting template concentration, a cycle profile was performed for each tissue. An average sample was created by mixing equal amounts of cDNA from all of the RT reactions from a single tissue type. PCR was performed using the 'average sample' template cDNA for between 20 and 40 cycles using primers specific for COX-1, COX-2 and GAPDH. PCR products were dotted onto Hybond $\mathrm{N}$ membranes (Amersham Pharmacia Biotech, Little Chalfont, Bucks, UK) and hybridised overnight to the appropriately radiolabelled cDNA probe (Slater et al. 1994). Membranes were washed to high stringency conditions with $0 \cdot 1 \times$ sodium citrate buffer at $65^{\circ} \mathrm{C}$, and Cerenkov counted (Johnson 1969). In these experiments optimal cycle numbers were: 35 for COX-1 in amnion and choriondecidua, 31 and 33 for COX-2 in amnion and chorion-decidua respectively, and 22 for GAPDH in all three tissues. These cycle numbers were used in subsequent experiments. To control for RNA concentration the expression of COX-1 and COX-2 was calculated as a ratio to that of GAPDH for each individual sample.

\section{Western analysis}

Protein extracts were prepared from fetal membrane samples by homogenisation in 10 vols T-Wash (50 mM Tris buffer, $10 \mathrm{mM}$ EDTA, 1\% Triton-100, with $10 \mathrm{mM}$ phenylmethylsulfonyl fluoride, $4 \mu \mathrm{g} / \mathrm{ml}$ pepstatin and $0.5 \mu \mathrm{g} / \mathrm{ml}$ leupeptin) for $30 \mathrm{~s}$. Proteins $(20 \mu \mathrm{g})$ were separated on a 10\% SDS-PAGE gel and transferred onto Hybond ECL nitrocellulose membranes (Amersham Pharmacia Biotech). Membranes were blocked in 5\% Marvel, $0 \cdot 1 \%$ Tween in PBS and incubated with either COX-1 or COX-2 specific antibodies (Santa Cruz Biotechnology, Santa Cruz, CA, USA) at a dilution of 1:500. Membranes were washed in $0 \cdot 1 \%$ Tween in PBS and incubated with anti-goat $\mathrm{IgG}$-horseradish peroxidase secondary antibody (Santa Cruz Biotechnology) at a dilution of 1:2000. Antibody specificity was confirmed using positive controls. Human platelets were used as a 
positive control for COX-1 and interleukin-1 $\beta$ stimulated human lymphocytes for COX-2. Western autoradiographs were quantified by digital densitometry.

\section{Fetal membrane COX activity and prostaglandin synthesis}

Prostaglandin synthesis from exogenous substrate sources by fetal membranes was measured to assess COX activity. Membranes were washed in PBS, and $2 \mathrm{~cm}$ discs of separated amnion and chorion were cut and suspended in serum-free medium 199 for $1 \mathrm{~h}$. Membrane discs were then incubated with fresh medium containing arachidonic acid $(30 \mu \mathrm{M})$ for $15 \mathrm{~min}$. Prostaglandin $\mathrm{E}_{2}$ concentration in the medium was measured by RIA according to manufacturer's instructions (Sigma-Aldrich, Poole, Dorset, UK). To assess prostaglandin synthesis from endogenous substrate sources intact fetal membrane discs were suspended in $1.5 \mathrm{ml}$ serumfree medium 199 with insulin $(1 \mu \mathrm{M})$, transferrin $(0 \cdot 1 \mu \mathrm{M})$ and selenium $(0 \cdot 05 \mu \mathrm{M})$ (Sigma-Aldrich) for $2 \mathrm{~h}$. Prostaglandin $\mathrm{E}_{2}$ concentration was measured by enzyme immunoassay (Amersham Pharmacia Biotech).

\section{Statistical analysis}

Data were analysed in groups, respectively estimating the mean and standard error before comparison was made using one way analysis of variance (ANOVA). Differences between groups were assessed using Fisher's exact test. Statistical significance was assumed if $P<0 \cdot 05$.

\section{RESULTS}

COX mRNA expression, as a ratio to the expression of the constitutively expressed GAPDH, was compared among ten gestational age groups. COX-1 mRNA expression in amnion and in chorion-decidua was low throughout pregnancy and did not change with gestational age or the onset of labour (Fig. 1). COX-2 mRNA expression in amnion and in chorion-decidua was low or undetectable until the second trimester, when it then increased towards term and doubled with labour (Fig. 2). ANOVA showed a significant effect of gestational age and labour on COX-2 expression both in amnion and in chorion. There was no correlation between COX-1 expression and gestational age.

Western analysis showed $\mathrm{COX}-2$ protein at $72 \mathrm{kDa}$ and COX-1 protein at $70 \mathrm{kDa}$. Protein

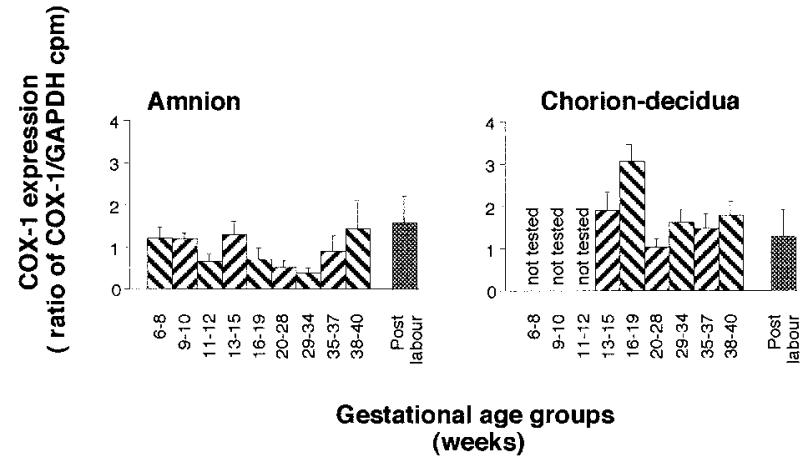

FIGURE 1. Expression of COX-1 mRNA, by RT-PCR, in amnion and chorion-decidua throughout gestation. Results are expressed as means and s.E. of the ratio of c.p.m. COX-1/GAPDH from gestational age groups; 6-8 weeks $(n=4), 9-10$ weeks $(n=4), 11-12$ weeks $(n=6)$, 13-15 weeks $(n=8), 16-19$ weeks $(n=4), 20-28$ weeks $(n=4), 29-34$ weeks $(n=6), 35-37$ weeks $(n=6), 38-40$ weeks (prior to labour) $(n=6)$, and 38-40 weeks (after labour) $(n=6)$.

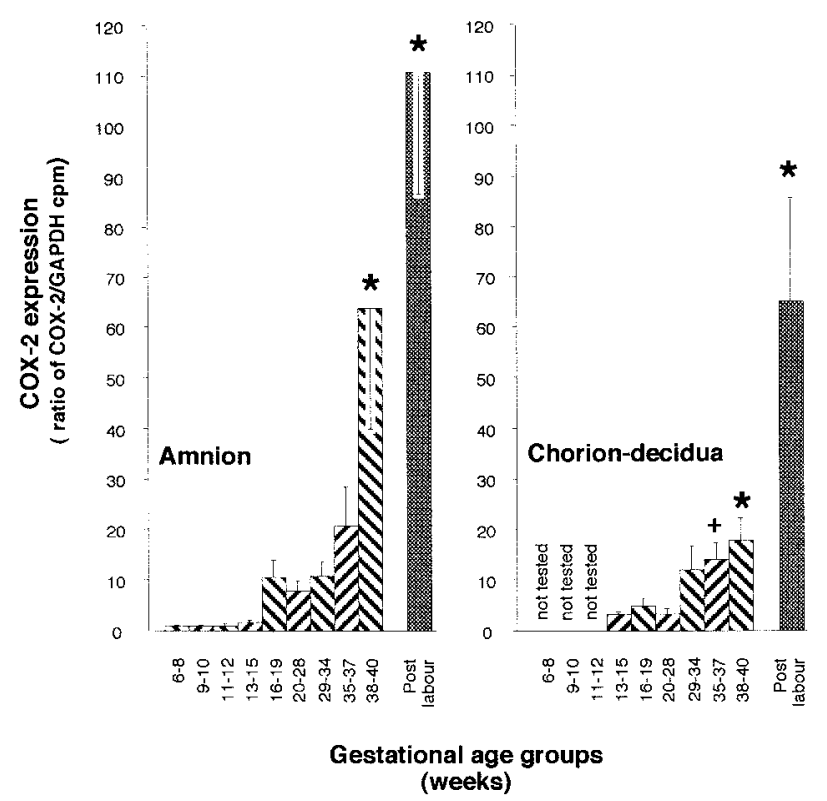

FIGURE 2. Expression of COX-2 mRNA, by RT-PCR, in amnion and chorion-decidua throughout gestation. Results are expressed as means and s.E. of the ratio of c.p.m. COX-2/GAPDH from gestational age groups; 6-8 weeks $(n=4), 9-10$ weeks $(n=4), 11-12$ weeks $(n=6), 13-15$ weeks $(n=8), 16-19$ weeks $(n=4), 20-28$ weeks $(n=4), 29-34$ weeks $(n=6), 35-37$ weeks $(n=6), 38-40$ weeks (prior to labour) $(n=6)$, and $38-40$ weeks (after labour) $(n=6)$. In both amnion and chorion-decidua ANOVA showed a significant effect of gestational age upon COX-2 expression $(P<0 \cdot 05)$. * $P<0 \cdot 05$ compared with all other groups; $+P<0 \cdot 05$ compared with all groups below 28 weeks. 


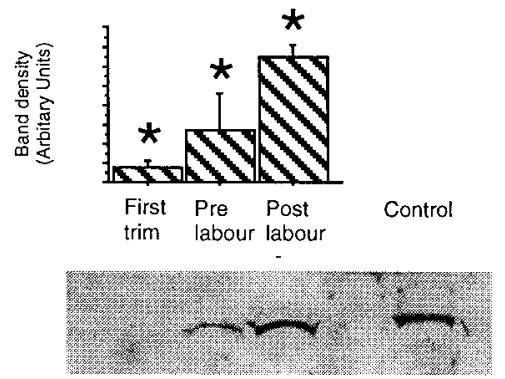

Amnion

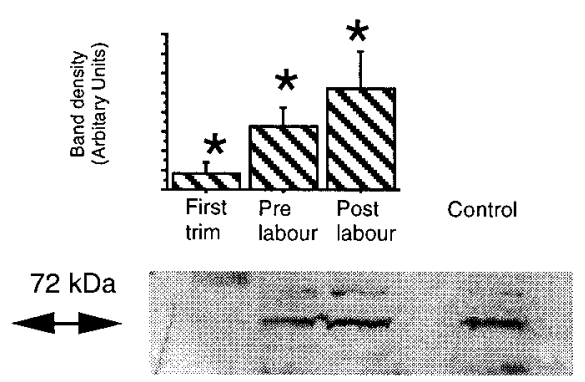

Chorion-decidua

FIGURE 3. Western blot analysis of COX-2 protein in fetal membranes. Lower panels show original gels; upper panels show densitometric analysis of blots (means \pm s.E., $n=4$ ). Expression of COX-2 protein was compared in fetal amnion and chorion-decidua from gestational age groups; $10-14$ weeks (first trimester), 38-40 weeks (prior to labour), and 38-40 weeks (after labour). ${ }^{*} P<0 \cdot 05$ compared with all other groups. $P$ values as assessed by ANOVA and Fisher's exact test.

concentrations of COX-1 were similar at all gestational ages and did not change significantly with gestational age or with labour in either amnion or chorion-decidua (data not shown). In amnion, protein concentrations of COX-2 increased from almost undetectable levels in the first trimester to maximum levels in samples collected after labour (Fig. 3). In chorion-decidua, COX-2 protein concentration increased significantly between the first trimester and term. There was also a significant difference between chorion-decidua collected before and after labour.

COX activity was assessed in three gestational age groups, 10-14 weeks, 38-40 weeks prior to labour, and 38-40 weeks after labour. In amnion, COX activity increased between the first and third trimesters and was further increased in tissues collected following labour (Fig. 4). In choriondecidua there was no change in activity between the first and third trimesters, but there was a significant increase in activity following the onset of labour. Production of prostaglandin $\mathrm{E}_{2}$ from endogenous substrate sources in intact fetal membranes increased between the first and third trimesters, but there was a decrease post-labour when compared with pre-labour (Fig. 5).

\section{DISCUSSION}

During pregnancy the uterus expands to accommodate the growing fetus and placenta whilst remaining relatively quiescent, and the cervix remains firm and closed. At term these changes reverse to allow the uterus to contract, and the cervix to soften and dilate. Lye (1994) has suggested that labour is the result of the activation of a 'cassette of contraction associated proteins' which might include gap junction proteins, oxytocin and prostaglandin receptors. We have previously shown that, at the mRNA level, it is principally COX-2 which is expressed in both amnion and chorion-decidua, and that its expression increases with the onset of labour, whilst the expression of COX-1 in both tissues is unchanged (Slater et al. 1995, 1998). We

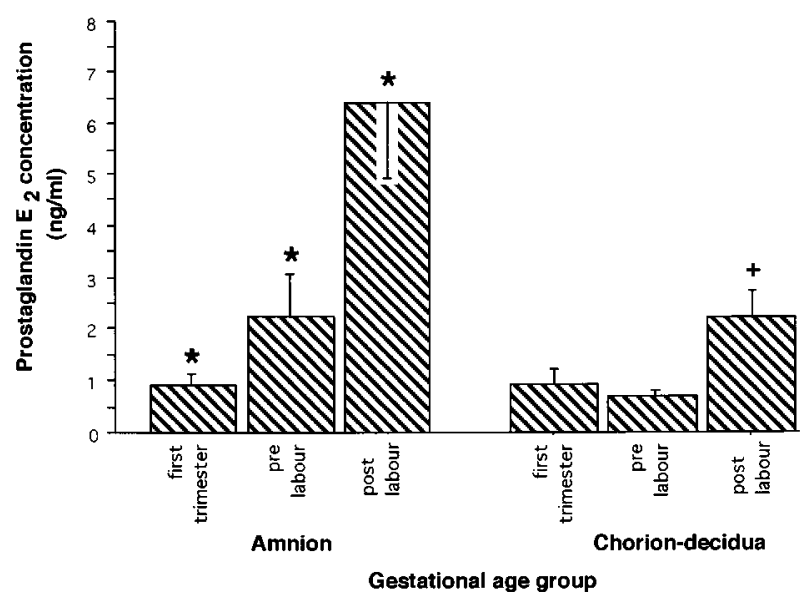

FIGURE 4. Assay of COX activity in amnion and chorion-decidua. Production of prostaglandin $\mathrm{E}_{2}$ by fetal membranes from exogenous arachidonic acid was compared between 10-14 weeks (first trimester), 38-40 weeks (prior to labour), and 38-40 weeks (after labour) $(n=5)$. Membranes were incubated with $30 \mu \mathrm{M}$ arachidonic acid for $15 \mathrm{~min}$ and prostaglandin $\mathrm{E}_{2}$ production was measured by RIA. Means \pm s.E., $* P<0 \cdot 05$ compared with all other groups; $+P<0 \cdot 05$ compared with term pre-labour group. $P$ values as assessed by ANOVA and Fisher's exact test. 


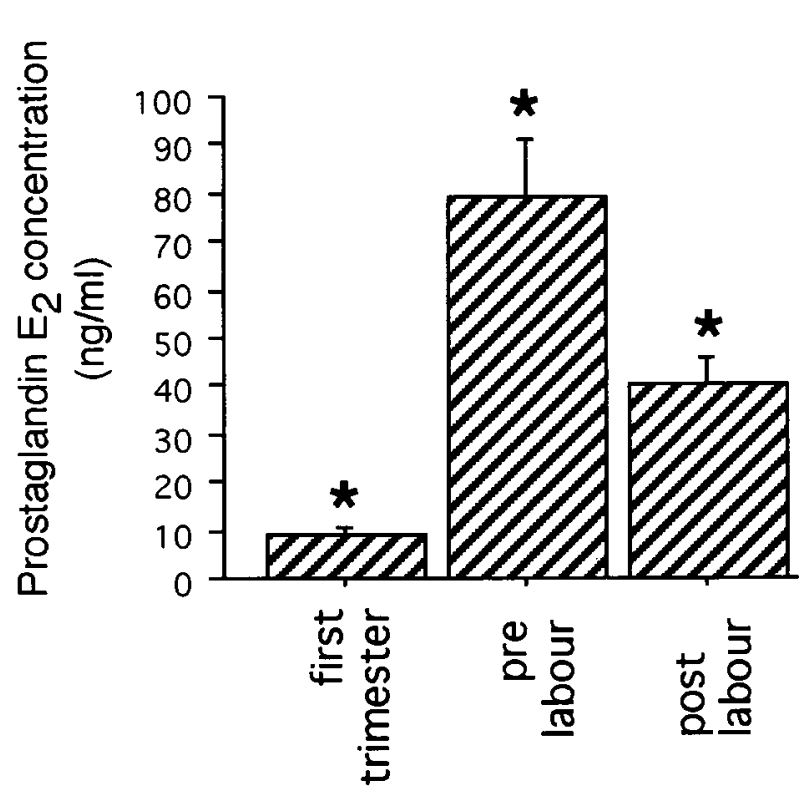

FIGURE 5. Production of prostaglandin $\mathrm{E}_{2}$ by fetal membranes from endogenous arachidonic acid was compared between 10-14 weeks (first trimester), 38-40 weeks (prior to labour), and 38-40 weeks (after labour) $(n=5)$. Membranes were incubated in medium for $2 \mathrm{~h}$ and the prostaglandin $\mathrm{E}_{2}$ produced measured by ELISA. Means \pm S.E., $* P<0.05$ compared with all other groups. $P$ values as assessed by ANOVA and Fisher's exact test.

have confirmed our hypothesis that the central prostaglandin synthetic enzyme COX might also be a member of the 'cassette of contraction associated proteins', by our finding of significant up-regulation of COX-2 expression in late pregnancy prior to labour. In sheep, the principal source of prostaglandins in late gestation is the placental cotyledon rather than the fetal membranes (Mitchell \& Flint 1977, Rice et al. 1988). Up-regulation of COX-2 expression in sheep placenta takes place gradually, as pregnancy advances, and COX-1 expression does not change (Wimsatt et al. 1993, Rice et al. 1995). The temporal pattern of COX expression is therefore similar in the two species, but in different tissues.

The major differences in COX-2 mRNA expression occur between the first and third trimesters, and before and after labour. Because of the difficulty of obtaining adequate numbers of tissue samples in the second and early third trimester, we confined COX activity studies and Western analysis to tissues obtained in the first trimester and at term, before and after labour. Western analysis showed increases in COX-2 protein concentrations between the first and third trimester and before and after labour, paralleling observations at the mRNA level.
We found no change in COX-1 expression at either the mRNA or protein level. These data, together with previous studies showing increased COX-2 expression in fetal membranes with the onset of labour (Hirst et al. 1995, Slater et al. 1995, 1998), suggest that it is up-regulation of COX-2 in fetal membranes which mediates the increased prostaglandin synthesis associated with labour and delivery in the human.

Prostaglandin synthesis requires liberation of substrate arachidonic acid through the activity of a phospholipase. We have studied COX activity by measuring synthesis of prostaglandins from exogenous arachidonic acid because both endogenous arachidonic acid concentrations and phospholipase $\mathrm{A}_{2}$ activity are known to fall in fetal membranes during labour (Curbelo et al. 1981, Skannal et al. 1997). This assay eliminates constraints on prostaglandin synthesis by endogenous substrate depletion or reduced phospholipase activity, but it does depend upon prostaglandin synthase $\mathrm{E}$ activity to produce prostaglandin $\mathrm{E}_{2}$. We also measured synthesis of prostaglandin $\mathrm{E}_{2}$ from intact fetal membranes without exogenous arachidonic acid, to examine their overall capacity for prostaglandin synthesis. Prostaglandin synthesis from endogenous sources increased between the first and third trimesters, in parallel with the increase in COX$2 \mathrm{mRNA}$ and protein concentrations. The decrease in prostaglandin synthesis in fetal membranes collected after labour is consistent with lower endogenous arachidonic acid concentrations (Curbelo et al. 1981) and phospholipase $\mathrm{A}_{2}$ activity (Skannal et al. 1997) following labour. The combination of increased COX-2 mRNA and protein expression, and maximum prostaglandin synthesis from endogenous substrate sources prior to labour, shows that increased prostaglandin synthesis within the fetal membranes precedes, and is therefore a cause, rather than a consequence, of labour.

\section{ACKNOWLEDGEMENTS}

This study was funded through grants made by Wellbeing and the Medical Research Council (UK).

\section{REFERENCES}

Bennett PR, Elder MG \& Myatt L 1987 The effects of lipoxygenase metabolites of arachidonic acid on human myometrial contractility in vitro. Prostaglandins 33 837-844.

Bennett PR, Slater DM, Sullivan MHF, Elder MG \& Moore GE 1993 Changes in arachidonic acid metabolism in amnion cells associated with increased cyclo-oxygenase gene 
expression at parturition. British Fournal of Obstetrics and Gynaecology 100 1037-1042.

Crankshaw DJ \& Dyal R 1994 Effects of some naturally occurring prostanoids and some cyclo-oxygenase inhibitors on the contractility of the human lower uterine segment in vitro. Canadian Fournal of Physiology and Pharmacology 72 870-874.

Curbelo V, Bejar R \& Benirschke K 1981 Prostaglandin precursors in human placental membranes. Obstetrics and Gynaecology $\mathbf{5 7}$ 473-478.

Garfield RE, Tabb T \& Thilander G 1990 Intercellular coupling and modulation of uterine contractility. In Uterine Contractility, pp 21-40. Ed RE Garfield. Norwell, MA, USA: Serono Symposia.

Hirst JJ, Teixeira FJ, Zakar T \& Olson DM 1995 Prostaglandin endoperoxide-H synthase-2 expression increases in human gestational tissues with spontaneous labour onset. Reproduction, Fertility and Development 7 633-637.

Hla T \& Neilson K 1992 Human cyclo-oxygenase-2 cDNA. Proceedings of the National Academy of Sciences of the USA $897384-7388$.

Hla T, Farrell M, Kumar A \& Bailey JM 1986 Isolation of the cDNA for human prostaglandin $\mathrm{H}$ synthase. Prostaglandins 32 829-845.

Johnson MK 1969 Counting of Cerenkov radiation from 32P in nonaqueous media. Analytical Biochemistry 29 348-350.

Keirse MJ, Mitchell MD \& Turnbull AC 1977 Changes in prostaglandin $\mathrm{F}$ and 13,14-dihydro-15-keto-prostaglandin $\mathrm{F}$ concentrations in amniotic fluid at the onset of and during labour. British Fournal of Obstetrics and Gynaecology 84 743-746.

Liggins GC 1989 Initiation of labour. Biology of the Neonate $\mathbf{5 5}$ 366-375.

Lye S 1994 The initiation and inhibition of labour - toward a molecular understanding. In Seminars in Reproductive Endocrinology, vol 12, pp 284-294. Ed MD Mitchell. New York, USA: Thieme Medical Publishers, Inc.

MacDonald PC \& Casey ML 1993 The accumulation of prostaglandins $(\mathrm{PG})$ in amniotic fluid is an after effect of labour and not indicative of a role for $\mathrm{PGE}_{2}$ or $\mathrm{PGF}_{2 \alpha}$ in the initiation of human parturition. Fournal of Clinical Endocrinology and Metabolism 76 1332-1339.

Mitchell MD \& Flint A 1977 Prostaglandin concentrations in intrauterine tissues from late pregnant sheep before and after labour. Prostaglandins 14 563-569.

Rice GE, Wong MH \& Thorburn GD 1988 Gestational changes in prostaglandin synthase activity of cotyledonary microsomes. Fournal of Endocrinology 118 265-270.

Rice GE, Freed KA, Aitken MA \& Jacobs RA 1995 Gestational and labour associated changes in relative abundance of prostaglandin $\mathrm{G} / \mathrm{H}$ synthase- 1 and -2 mRNA in ovine placenta. Fournal of Molecular Endocrinology 14 237-244.

Romero R, Munoz H, Gomez R, Parra M, Polanco M, Valverde V, Hasbun J, Garrido J, Ghezz F, Mazor M, Tolosa JE \& Mitchell MD 1996 Increase in prostaglandin bioavailability precedes the onset of human parturition. Prostaglandins, Leukotrienes and Essential Fatty Acids $\mathbf{5 4}$ 187-191.

Saeed SA \& Mitchell MD 1982 Formation of arachidonic acid metabolites by human fetal membranes, uterine decidua vera and placenta. Prostaglandins, Leukotrienes and Medicine $\mathbf{8}$ $635-640$.

Skannal DG, Brockman DE, Eis AL, Xue S, Siddiqi TA \& Myatt L 1997 Changes in activity of cytosolic phospholipase $\mathrm{A}_{2}$ in human amnion at parturition. American Fournal of Obstetrics and Gynecology 177 179-184.

Skinner KA \& Challis JRG 1985 Changes in the synthesis and metabolism of prostaglandins by human fetal membranes and decidua at labor. American Fournal of Obstetrics and Gynecology 151 519-523.

Slater DM, Berger L, Newton R, Moore GE \& Bennett PR 1994 The relative abundance of type 1 to type 2 cyclo-oxygenase mRNA in human amnion at term. Biochemical and Biophysical Research Communications 198 304-308.

Slater DM, Berger L, Newton R, Moore GE \& Bennett PR 1995 Changes in the expression of types 1 and 2 cyclo-oxygenase in human fetal membranes at term. American Fournal of Obstetrics and Gynecology 172 $77-82$.

Slater DM, Allport V \& Bennett PR 1998 Changes in the expression of the type-2 but not the type-1 cyclooxygenase enzyme in chorion-decidua with the onset of labour. British Fournal of Obstetrics and Gynaecology 105 $745-748$

Smieja Z, Zakar T, Walton JC \& Olson DM 1993 Prostaglandin endoperoxide synthase kinetics in human amnion before and after labour at term and following preterm labour. Placenta 14 163-175.

Walsh SW 1989 5-Hydroxyeicosatetraenoic acid, leukotriene C4 and prostaglandin $\mathrm{F}_{2 \alpha}$ in amniotic fluid before and during term and preterm labor. American Fournal of Obstetrics and Gynecology 161 1352-1360.

Wimsatt J, Nathanielsz PW \& Sirois J 1993 Induction of prostaglandin endoperoxide synthase isoform-2 in ovine cotyledonary tissues during late gestation. Endocrinology 133 $1068-1073$.

REVISED MANUSCRIPT RECEIVED 6 October 1998 